Australian Geographer Special Issue: 'Creative Geographies: Tales from the Margins'

\title{
Postcards from somewhere: 'marginal' cultural production, creativity and community
}

\begin{abstract}
This paper focuses on a case study of local postcard production in a rural community in Western Australia. Drawing on in-depth interviews with key producers of these postcards the analysis presented explores perceptions of and contexts for the emergence of this production, in turn examining the notion of 'creativity' articulated and privileged by this cultural work. Connections are identified between the making of postcards, the broader historical field of local cultural work and the construction of community. This, in turn, forms the basis for consideration of the role and relativity of 'marginality'.
\end{abstract}

Key words: creativity, cultural industries, community, postcards, rural Australia

\author{
Robyn Mayes \\ John Curtin Institute of Public Policy \\ Curtin University \\ GPO Box U1987 \\ Perth WA 6845 \\ Australia \\ Phone: + 6180417951492 \\ Fax: +61 892663658 \\ Email: R.Mayes@curtin.edu.au
}

Word count 5156 


\section{Introduction}

In the summer heat of January 2007, after driving for several hours on seemingly endless country roads through sparsely inhabited bush and farm land, I arrived in the rural Shire of Ravensthorpe, Western Australia. This was to be the first of numerous enjoyable visits over the following two years as part of an ethnographic study of community change and place identity. ${ }^{i}$ First settled in 1868, the Shire of Ravensthorpe lies some 550 kilometers south-east of the capital city of Perth (Shire of Ravensthorpe 2009). Agriculture, in particular broad-acre farming of grains and sheep, has consistently been a principal industry; farming continues by third and fourth generation pioneer families (Southern Scribes 2000) and also by first and second generation settlers who arrived in the 1960s to take up new land farm blocks released, for example, under the Conditional Purchase Scheme (Williams 2009). Mining has been a part of the Shire from the discovery of gold in the late 1890s, through to the more recent and ultimately brief operational presence of a large-scale BHP Billiton nickel mine which opened in May 2008 and closed in January 2009 (Shire of Ravensthorpe 2009). Prior to the rapid increase in population and profound demographic change occurring as a result of the accommodation of some 350 mine staff and families, the Shire's residents numbered 1,387 in 1996, 1,466 in 2001 and 1,951 in 2006 (ABS 2007). This small population is dispersed among the communities of Hopetoun (a retirement coastal settlement and, briefly, home to the majority of residential mine-staff); Ravensthorpe (seat of local government and service center for surrounding agricultural industries); Jerdacuttup (a small community farming land released in the 1960s), Munglinup (a farming community which is also part of Esperance Shire) and Fitzgerald (also a farming community and which lost its school recently due to lack of students). Over two-thirds of the Shire's 13,000 square kilometers remains as natural bush land and national parks including the eastern half of the Fitzgerald Biosphere Reserve (Shire of Ravensthorpe 2006).

On this first visit to this Shire I was fascinated, and surprised, to discover the Ravensthorpe Visitor Center and Museum (open on a Sunday) overflowing with 
locally-produced books, wrapping paper, screen-printed teatowels, jewellery, and stands of postcards, to name just a small selection of goods. In this and subsequent visits I learned of the annual Wildflower Show and local herbarium. I also learned that the Centenary Mural Sculpture on the main street was locally designed and crafted, and that the home page image on the Shire web site is a local landscape painted by a resident artist. I admired the community-developed Hopetoun entry sign and artwork along with the public wall murals painted by local community groups. I was introduced to numerous groups such as the Southern Scribes, the Jerdacuttup Players, and the Boot Scooting Club. During my time in the area I have had the pleasure of attending plays, book launches, the $25^{\text {th }}$ Annual Wildflower Show, festivals, community concerts, and have conducted some of my interviews in the Jerdacuttup Community Hall surrounded by an impressive array of theatre arts equipment. Through friends in the area and the reading of the local newspaper I am aware of numerous events that I wasn't fortunate enough to attend: week-long writer-in-residence programs, a performance of a locally-authored opera, numerous workshops and, more recently, the opening of the Ravensthorpe District Art Group Dunnart Studio Gallery. ${ }^{\text {ii }}$

My surprise at finding this rich and vibrant cultural life, this abundance and range of cultural enterprise and production, is not only a somewhat embarrassing manifestation of my (urban) ignorance if not arrogance; it can also be read as a symptom of culturally widespread assumptions which privilege urban Australia as normative site of and place for creativity and cultural industry. This paper explores cultural work in Ravensthorpe in relation to urban-centric discourses around the cultural industries elaborated in the introduction to this volume. It does so through focusing on the local production of postcards, all of which feature images from the area, principally land and sea scapes, flora, and town buildings (see plates 1 to 6). These postcards are available exclusively from town vendors such as the Ravensthorpe Post Office, Hopetoun Telecenter, and Ravensthorpe Visitor Centre. With a thirty-year history and involving 20 residents (13 of whom are female) across this period, this production includes the work of individuals and voluntary community committees such as Ravensthorpe Hopetoun Area Promotions (RHAPS, and informal art groups. As I have argued elsewhere (Mayes 2010) this local 
production of postcards plays an important role in the ongoing construction and circulation of place identity and in the representation and embodiment of rurality more broadly. To make postcards is to participate in and engage with a substantial and highly conventionalised cultural industry and communicative practice with a significant role in the (potentially mass) production and circulation of (popular) meaning (Kennedy 2005; Pritchard \& Morgan 2005; Siegel 2000). Aimed squarely, though not exclusively, at an external market/audience and partly a response to marginalization by the commercial postcard industry-none of the commercial firms offer postcards carrying images of the Ravensthorpe region - this postcard production is suggestive of the multi-scalar spaces and practices (and possible specificities) of rural cultural industries and creativity. The analysis offered here pays particular attention to the forms and contexts of creativity encoded in and enabling this production, together with the role of geographical distance and cultural isolation in its emergence. The paper begins with a brief description of the empirical data collection and then situates the study within broad understandings of 'cultural industry' and 'creativity'. Thereafter, the postcard producers' perceptions of, and local contexts for, this production are examined in light of understandings of, and linkages between, creativity and community. The paper concludes by mapping some of the ways in which this 'marginal' practice engages with dominant and alternative models of cultural industry.

\section{Case study and context}

Though drawing on the wider ethnographic study mentioned previously, primarily in order to elucidate broader social, cultural and historical contexts, the discussion is grounded in five semi-structured interviews conducted as part of this broader project. These five interviewees were selected on the basis of substantial involvement in the production of local postcards. All interviewees are female and four are long-term local residents living in the area upwards of forty years, while one interviewee had been living in the community close to two years. One individual producer of an extensive range of postcards, and the only male with substantial involvement, could not be contacted for interview. Though this sample is small it nevertheless captures a sizable percentage of local producers, and spans not only individual and collaborative participation but also 
past and present production. Interviews were semi-structured around reasons for and benefits of becoming involved in making postcards, the processes of production including the ways in which images were selected, and their market success in terms of sales and most popular images. Interviews were recorded and transcribed.

The terms 'cultural' and 'creative,' as is widely argued in the literature, are often uncritically conflated and at risk of becoming so capacious as to become meaningless (Galloway \& Dunlop 2007; Warde 2002). As such they require some clarification in order to delineate the conceptual boundaries of the ensuing analysis. Precise definition of cultural industries, however, is far from easy (Drake 2003). Inclusion of a specific activity involves a complex qualitative assessment necessarily informed by social and spatial contexts (Banks 2007). Notwithstanding this and further difficulties around determining relative proportions of cultural and functional worth, the category 'cultural industries', as a distinctive subset of the broader creative industries, is defined not only as privileging symbolic meaning (over 'use value'), and thus a distinctive cultural creativity, but in addition as employing large-scale or mass production methods (Banks 2007; Galloway \& Dunlop 2007). Much of the Shire of Ravensthorpe’s cultural production described above sits squarely in the 'creative arts' sector: together with the use of semiindustrial and small-scale production methods, this positions the cultural work undertaken in Ravensthorpe as 'peripheral' to the cultural industries (Galloway \& Dunlop 2007). Similarly, 'creativity' is seemingly resistant to consensual definition, though the literature convincingly emphasizes its collective and social roots (Bilton \& Leary 2002; Drake 2003) and the necessary role of social capital (Scott 1999).

\section{Making postcards in Ravensthorpe}

Interviewees were not directly asked about 'creativity' and none of them used the term in any context. Rather, interviewees noted personal characteristics such as having 'a mind that just keeps ticking over' so that the postcard work is 'just a little hobby to keep me out of mischief'. In the words of another interviewee: 'it's an interest'. Importantly this interest is elaborated upon as facilitating interactions with other groups; one interviewee gave the example of having taken a photograph of 'an unusual flower' which then led to 
discussions with herbarium enthusiasts in an attempt to identify the species and understand why this particular specimen did not exhibit typical petal structures. Yet another interviewee became involved by virtue of committee membership:

I found myself on the committee, not that I offered, but it just sort of happened.

They just left it to me. And I just sort of took all sorts of photographs and then we just put them in and said well we'll use this one and this one and this one.

In commenting on how she came to be involved in making postcards a further participant noted that 'we had a strong art group'. Romantic notions of the creative self, in which creativity arises naturally from essentialised and unique individual qualities (Banks 2007) are noticeably absent in these fundamentally self-effacing narratives. At the same time, the postcard work appears to be 'marginal.' It is just one local cultural enterprise among others. This stands in contrast to the creative focus on specialized forms described in the literature on (competitive) clusters around, for example, film making or jewellery production. The postcard work is further marginal in relation to the rest of the producer's life, as in the designation 'hobby'. Similarly, self-expression and conscious meaningmaking, and to a lesser extent the communication of ideas-hallmarks of culturally dominant understandings of individual creativity-were underplayed by interviewees. Instead emphasis was afforded to a desire to 'share' and, in the case of RHAPS production, to promote the area and fundraise for this purpose. In the case of the art collective, attention was concurrently on promotion of local artists, consistent with postcards as advertising and promotional artifact (Kohn 2003), and on redressing the above-mentioned local lack of postcards.

At some point in the discussion around how she became involved in making postcards, each interviewee made (often extensive) reference to the broader community, and to other cultural activities and products. They mentioned seemingly unrelated affiliations with, for example, the Southern Scribes or the Wildflower Show together with assertions about broader community involvement encapsulated in the following assertion: 'I'm pretty much a community person.' This production occurs not only in a broader field of local cultural work and community networks (Mayes 2010) but is also situated in a particular 'type' and history of community. The narratives offered by two producers with 
long-term residencies in the shire draw attention to the intertwined emergence of community and cultural work. This history begins with the arrival of new land farmers in the 1960s in Fitzgerald and Jerdacuttup. The method and allocation of this new land ensured that settlement occurred over a short period so that, in the words of one interviewee, in each area it was 'all basically new people'. In Fitzgerald 'a lot of people were from the Eastern States'. Those taking up new land in the Jerdacuttup area are described as coming

from all over the world really, you know. From Africa, from England, from America, from Switzerland, from Eastern States etc. and people from different walks of life-some in agriculture, some not, but all ending up with land. And it was quite eclectic; you know it was really quite exciting. Because we had a great mix. And we found lots of things started happening because of this.

These newcomers, implicitly, are not 'just' farmers, just as 'newness' and 'difference' are important characteristics not only in 'starting a community', but in starting cultural production in order to build community. As was explained:

we started a community with a whole group of us, we were all new land farmers together, nobody had any money. .... First of all, the community got together and raised money.... so that was the first part, was that we raised money and put money in to build a hall, school come church, come everything, but it was mainly for children. We had dances, and pictures, and very much to the fore of helping raise money for things and community-minded.

An important aspect of starting these communities was not only lack of infrastructurethere was literally nothing - but also distance from other settled areas and amenities. The task for the newcomers, according to these interviewees, and as numerous others in the broader ethnography proudly confirm, was to provide themselves with both infrastructure and a sense of community through shared work and social events. Fundraising through local cultural work was an ideal solution. As an example, the Jerdacuttup Players theatre group emerged from a Music Hall performance staged in 1972 as a fundraiser for a power plant for the local hall (Hatter 2009). Since then the group has produced 46 plays including at least one locally-authored piece between 1972 and 2006. These were performed in Jerdacuttup, Hopetoun and Ravensthorpe, occasionally in Munglinup, Lake 
King and, further a field, in Esperance. In this manner, the Players, together with other voluntary local community groups such as the Ladies Catering Group, funded improvements to the hall including 'dressing rooms, toilets, a supper room, tables, chairs, costume cupboards and stoves' (Hatter 2009, np) not to mention the specialized equipment and resources needed to maintain a viable drama group. These events not only require widespread community involvement in a range of creative, supportive and organisational roles, but also occur in, and reproduce, a sympathetic environment which in turn enabled connections with the other communities:

there used to be that comradeship-come-support feeling you know? If a community put on an event, you supported it cause you knew how much time and effort it took to put on an event. You always supported an event that was put on.

The community postcard production as a fundraising strategy (Mayes 2010) is part of this tradition of cultural work in the service of community needs. Presented by interviewees as marginal, though important, to their individual lives, cultural work and products more broadly are concurrently understood as central to 'community'.

Community group and individual postcard production occurs also in what can be termed a 'creative' environment. As noted earlier, one range of postcards came into existence through the proximity of other artists. Another interviewee pointed out that, 'Well we've got a lot of talented people in this place,' suggesting that the presence of like-minded or talented others in some proximity is an enabling factor. Attention, in addition, was also drawn to a sense of place-based differences within the Shire. Jerdacuttup in particular is perceived both internally and externally as a locus of creative, if not bohemian, difference.

Ravensthorpe always thought we were immoral and newcomers, you know were rather shocked by our goings on.

A sense of heightened community investment in cultural production informs this understanding of difference:

We have an Arts Council which has always been Jerdacuttup based; it's called the Ravensthorpe Arts Council but it was started by Jerdacuttup people and is still run 
by Jerdacuttup people and we've put on shows here and for years, and years, and years and years. ${ }^{\text {iii }}$

Each of the four long-term local participants had extended, close involvements with this 'new land' community.

Jerdacuttup, as a close-knit, 'artistic' and politically engaged community with a strong cultural-arts tradition, is confirmed in the broader ethnography as a perception widelyheld in the Ravensthorpe area. This difference is seen as valuable, and also as an irritation, as demonstrated in the following comments from a variety of residents from the other communities in the Shire:

Their plays are absolutely brilliant. Everybody raves about them. They've really got some really talented local farmers ... local people there.

When Jerdacuttup was a very new area they had a very strong art group down there. And they used to have film evenings and drama groups and whatever and the ... that generation has continued to foster that in their community and they still hold you know plays and they even had an open air concert last year. So they've really ... they have retained their identity through that group. It's quite a great little group and I mean that's not the only thing, but there's quite a few artistic people down there that have really worked to maintain their identity.

Jerdacuttup was always an elite arty-farty group. That's the way to describe them, the elite arty-farty group. And if there was going to be something ... how do I say it? Perhaps if they were going to go and save an orchard, it'd come from there.

Whether valued and appreciated or disparaged, Jerdacuttup is locally experienced and perceived as a hub of creative endeavour in a process in which creativity is no longer marginal. 


\section{Creativity and communities on the margins}

Interviewees' narratives around their involvement in the production of postcards, whether as individuals or as part of a committee, support an understanding of creativity as quotidian activity in the service of solving daily problems (such as lack of local postcards, the need to keep busy, fundraising) with an emphasis not so much on novelty but rather on 'usefulness' (e.g. Bilton \& Leary 2002). In this understanding, creativity is a 'multidimensional' and collective, if not collaborative, process arising from combinations of factors and relationships. The postcard production in Ravensthorpe Shire foregrounds a variety of layered motivations and relationships thus suggesting the 'diversity and contingency of forms of creative entrepreneurial behaviour' (Drake citing MacKinnon et al 2000). In addition this local practice indicates that the 'kind' of creativity and the conditions of emergence are closely interlinked. The connections to broader networks, projects and histories of community woven into the narratives presented here emphasize isolation or more specifically 'lack' as a positive stimulus when combined with a desire/need to create community; this isolation or lack is not individual but is rather geographic community isolation. Consequently, the Ravensthorpe Shire postcard work and broader context highlights the 'sociality of cultural industries' (Kong 2005; Scott 1999). This incorporates social bases, premised on the understanding that cultural production and consumption is embedded in social systems and relationships, along with social roles such as 'contributing to the development of cities as cultural and social entities', that is 'as places where people meet, talk, share ideas and desires, and where identities are formed' (Kong 2005 citing Bianchini 1993). The postcard production in Ravensthorpe Shire draws on a considerable store of accumulated social and symbolic capital. This regionally unique cultural work has its roots in substantial (and historical) local interactions both within and across communities, and a broader communal sense of, and pride in, creative endeavour. The limits of this endeavour, it is reasonable to surmise, are reproduced and negotiated in shared highly subjective perceptions of what is 'fun,' will serve the community best, will generate the most funds and opportunities for skills development, and make best use of existing local skills and resources. Place-based networks such as this tend to be associated with cities presented as logical site of (largerscale, economically potent) aggregation (Kong 2005). 
The overarching objective of establishing a sense of community, as historical context for local cultural production including but not limited to postcard production, in turn emphasizes collaborative creativity around cultural products for local consumption and participation. This local work is also suggestive of creativity as a means to enhance interaction rather than ('just') interaction as a means to enhance creativity, as privileged in much of the literature (see Drake 2003). Creativity, as defined above and in the eyes of the postcard producers interviewed, is in the service of 'community', so that creativity has a clear social role in the production of sense of community and the construction of both physical places and social spaces in which to meet, share ideas and negotiate individual and community identities. This is further evidenced by the wider local connections articulated between 'artistic' and 'community'-in particular community identity. Cultural industries offer opportunities for the negotiation and transformation of rural identities (Gibson 2002). The construction of Jerdacuttup as discrete community with distinctive social capital through creative practice-politically important for a small farming community which, in the words of one interviewee, has 'always been a small community' and 'always had to battle for things' - highlights creativity as both a social and political process (Banks 2007). It is not only community recognition if not standing that is achieved; individual members also are fashioned as 'talented' for example. It is important to keep in mind that this effacement of individual motivations and emphasis on community in these interviews may be informed by a gendered sense of self. The absence of the term 'creative' in interviewee descriptions of their work or selves may similarly have its roots in gendered experience. At the same time, however, 'artistic' is used to describe both the local cultural activity and individual personal characteristics, thus reinstating the Romantic notion of the creative individual. Worthy of further exploration, connections are evident between this 'artistic' practice and generalized critical politics as seen in the community perceptions of Jerdacuttup.

Postcard producers have either personal histories of involvement in numerous and various community activities or are able to activate the networks and, equally importantly, the ethos this has established. The newcomer too has been able to find a 
'space' in this environment and is able to utilize local social capital. Individual enterprise thus enacts a fluid interaction between collective creativity and networks as a fertile environment for individual production (see Drake 2003). There is no evident tension between the volunteer community producers and individual producers either in terms of access to market share or sense of validity of product as 'authentically' local.

The postcard producers, particularly in light of the range of other cultural work they undertake, and together with the broader group of local people engaged in cultural production of various forms, can be approached as constituting what Drake (2003) has tendered as an important feature of 'locality' in the context of cultural industries, that is 'a community of creative workers'. These participants are directly engaged in the production of commodities in which symbolic meaning is privileged, and do so collectively, and potentially as a 'creative class'. This status indicates possession of desirable/ sought after skills available as a 'talent pool' (Bontje \& Musterd 2009); implicit in this are attendant exclusions and uneven power relations. Indeed, the foregrounding of (enabling and empowered) community is not to suggest that the community called into being in this practice is inclusive, apolitical or utopian. There is also the matter of who can contribute (aside from perceptions or evidence of talent); ability to participate in independent (and here largely unpaid) cultural work has much to do with 'lifecycle' stages (McRobbie 2002). The founding members of these new land communities were predominantly young (middle-class) couples either with young families or on the verge of starting families. The postcard work is currently the domain of a retirement-age cohort, and as indicated at the outset is dominated by women. Farming is also an industry that lends itself to community development: first, in this area the majority of farmers were land owners developing their own businesses with attendant autonomy; second, land management does not stop at the fence and requires collaboration with neighbours; third, this group was all similarly cash-poor; and, forth, farming is a cyclical business with down-time. 


\section{Conclusion: engaging markets and practice-led cultural industries}

As has been convincingly demonstrated by numerous scholars there are inherent tensions in the economic and social roles of cultural activities' (Kong 2005, P. 65). Broadly, the 'creative economy', though premised as a means to 'overcome social and economic inequalities and effect future economic growth’ (Banks 2007, P. 71), has been shown to privilege 'economic growth' while neglecting those who cannot participate and, at the same time, effecting active exclusions (Atkinson \& Easthope 2009). Importantly, as Galloway and Dunlop (2007, P. 29) argue, positioning 'the cultural sector as part of the wider creative economy simply subsumes it within an economic agenda' thus occluding the public benefits provided by culture. More specifically, making money, as overarching objective in the creative economy, 'structures how creativity is defined, developed and employed' (Banks 2007, P. 73). The production of postcards in the Shire of Ravensthorpe whether undertaken by individuals or by community groups does not have making money as its central objective (Mayes 2010). Even so, the postcard production is, to some extent, about finding a place in the market for postcards, just as it requires for its existence, and forms links to, (global) tourism markets and capital flows. While these postcard producers are focused on meeting very local needs, production is not entirely contained by this context; one individual producer has ambitions to extend her production to represent and sell from other regions, another producer had to change production methods in order to comply with commercial standards of production, and another producer felt the need to note that 'it's done like a proper postcard.' In this way the market informs this local practice which in turn does not / cannot operate outside the market.

Meanwhile this production has been shown to reject normative capitalist imperatives to focus on maximising profits and to strive for wealth accumulation, for example in producers' marginal interest in, if not disregard for, financial gain (in part encoded in choice of product). Rather this local production emphasizes internal (participatory) rewards as associated with 'practice led economies' (Banks 2007). Though unlikely to qualify as 'alternative' production, the practice-led emphases in this postcard work offer at least a glimmer of 'utopian promise' which Banks (2007) insists imbues creative 
cultural production despite convincing arguments demonstrating the pervasive (if not total) capitalistic appropriation of the culture industry. The potential for cultural criticism or subversion is similarly difficult to assess, though this rural cultural work and creativity may well provide a source of, or creative field for, stimulating not only 'new' but also alternative cultural products.

This case-study of postcard production points to the importance of recognizing and understanding rural individual and community cultural work as a wide-reaching and multi-faceted component of rural and community life, and also as providing insights into progressive and transformative potentials in the creative industries. Within the broader normative conceptualization of the cultural industries the postcard production undertaken in Ravensthorpe is marginalized on several counts: it is non-urban, non-industrial, nonmarket oriented. At the same time this activity occurs in conditions similar to those identified as underpinning urban or clustered cultural industry: networks, stimulus, and community traditions. This sort of activity may well be taking place in urban communities, but in this rural community it is not only highly visible but also central to the material and symbolic realities of community life. Rural places and communities have much to teach us about creativity and cultural production particularly as occurs when (substantially) decoupled from 'economy', along with the means by which the contemporary reduction of the cultural industries to a capitalist economy might be resisted.

\footnotetext{
${ }^{i}$ Much of this research was conducted during an independent Fellowship funded by Alcoa Foundation's Conservation and Sustainability Program at the Alcoa Research Centre for Stronger Communities at Curtin University of Technology.

ii This list is far from complete and is not intended to suggest that the noted items are more 'cultural' or in any other way worthier than those not mentioned.

iii This subjective view is not offered as historically accurate.
}

\section{Acknowledgements}

I would like to extend a warm 'thank you' to the 'postcard producers of Ravensthorpe Shire' for sharing their experiences with me and commenting on the draft paper. Sincere thanks also to Chris Gibson for the invitation to contribute to this issue. 


\section{References}

ARCHER, A.W. (2008) Ravensthorpe then and now Third revised edition, Ravensthorpe Historical Society, Ravensthorpe.

ATKINSON, R. \& EASTHOPE, H. (2009) 'The Consequences of the Creative Class: the pursuit of creativity strategies in Australia's cities', International Journal of Urban and Regional Research 33:1, pp. 64-79.

AUSTRALIAN BUREAU OF STATISTICS (ABS) (2007) 2006 Census Tables: Ravensthorpe (S) LGA, accessed August 2007.

BANKS, M. (2007) The politics of cultural work, Palgrave Macmillan, Houndmills, Basingstoke.

BILTON, C. \& LEARY, R. (2002) 'What can managers do for creativity? Brokering creativity in the creative industries', International Journal of Cultural Policy 8:1, pp.4964.

BONTJE, M. \& MUSTERD, S. (2009) 'Creative industries, creative class and competitiveness: expert opinions critically appraised’, Geoforum 40 (5), pp. 843-52.

DRAKE, G. (2003) '’This place gives me space': place and creativity in the creative industries', Geoforum 34, pp 511-524.

GALLOWAY, S. \& DUNLOP, S. (2007) 'A critique of definitions of the cultural and creative industries in public policy’, International Journal of Cultural Policy 13:1, pp. $17-31$.

GIBSON, C. ( 2002) 'Rural transformation and cultural industries: popular music on the New South Wales far north coast', Australian Geographical Studies 40:3, pp. 337-356.

HATTER, M. (2009) 'Jerdacuttup Players' in Williams, A. (ed) Where the Boodie Rats used to dig: A scrapbook history of Jerdacuttup Pioneer Farming Community, Jerdacuttup Community Association, Ravensthorpe WA, pp.340-43.

KENNEDY, C. (2005) 'Just perfect! The pragmatics of valuation in holiday postcards' in Jaworski, A \& Pritchard, A. (eds) Discourse, Communication and Tourism Tourism and Cultural Change, Chanel View, Clevedon, pp. 223-246.

KOHN, A. (2003) 'Let's put our (post) cards on the table', Visual Communication 2, pp. 265-284. 
KONG, L. (2005) 'The sociality of cultural industries', International Journal of Cultural Policy 11:1, pp. 61-76.

MAYES, R. (2010). 'Doing cultural work: local postcard production and place identity in a rural shire', Journal of Rural Studies 26, pp. 1-11.

McROBBIE, A. (2002) 'From Holloway to Hollywood: happiness at work in the new cultural economy?' in du Gay, P. \& Pryke, M. (eds) Cultural Economy: Cultural Analysis and Commercial Life, Sage, London, pp. 97-114.

PRITCHARD, A. \& MORGAN, N. (2005) 'Representations of 'ethnographic knowledge'; early comic postcards of Wales' in Jaworski, A. \& Pritchard, A. (eds) Discourse, Communication and Tourism Tourism and Cultural Change, Chanel View, Clevedon, pp. 53-75.

SCOTT, A. (1999) 'The cultural economy: geography and the creative field' Media, Culture \& Society 21, pp. 807-817.

SHIRE OF RAVENSTHORPE (2006) Community information: a few facts, brochure available locally and from the Shire webpage: http://www.ravensthorpe.wa.gov.au/ (accessed 26 October 2006).

SHIRE OF RAVENSTHORPE (2009) 'Mining', available from: http://www.ravensthorpe.wa.gov.au/mining accessed 20 January 2010).

SIEGEL, L. (2000) 'Filth in the wrong people's hands: postcards and the expansion of pornography in Britain and the Atlantic World, 1880-1914', Journal of Social History 33(4), pp. 859-85.

SOUTHERN SCRIBES (2000) And the dingoes howled: stories from the bush Southern Scribes, Ravensthorpe.

WARDE, A. (2002) 'Production, consumption and 'cultural economy', in du Gay, P. \& Pryke, M. (eds) Cultural economy: cultural analysis and commercial life, Sage, London, pp. 185-200.

WILLIAMS, A. (2009) Where the Boodie Rats used to dig: A scrapbook history of Jerdacuttup Pioneer Farming Community, Jerdacuttup Community Association, Jerdacuttup, WA. 